\section{Kidney \\ Blood Pressure Research}

Kidney Blood Press Res 2015;40:141-152

DOI: $10.1159 / 000368490$

(C) 2015 S. Karger AG, Basel

www.karger.com/kbr

$1423-0143 / 15 / 0402-0141 \$ 39.50 / 0$

Accepted: February 04, 2015

This is an Open Access article licensed under the terms of the Creative Commons AttributionNonCommercial 3.0 Unported license (CC BY-NC) (www.karger.com/OA-license), applicable to the online version of the article only. Distribution permitted for non-commercial purposes only.

\title{
Renal Effects of Coronary Artery Bypass Graft Surgery in Diabetic and Non- Diabetic Patients: A Study with Urinary Neutrophil Gelatinase-Associated Lipocalin and Serum Cystatin C
}

\author{
Oguzhan Arun ${ }^{\mathrm{a}} \quad$ Gulperi Celik ${ }^{\mathrm{b}} \quad$ Bahar Oc $^{\mathrm{a}}$ Ali Unluc Jale Bengi Celik ${ }^{\mathrm{a}}$ \\ Mehmet $\mathrm{Oc}^{\mathrm{d}}$ Ates Duman ${ }^{\mathrm{a}}$ \\ aDepartments of Anesthesiology and Reanimation; ${ }^{\mathrm{b}}$ Nephrology; ${ }^{\mathrm{c} B i o c h e m i s t r y ;}{ }^{\mathrm{d}}$ Cardiovascular \\ Surgery; Selcuk University, Faculty of Medicine, Selcuklu Konya, Turkey
}

\section{Key Words}

Acute kidney injury $\cdot$ Anesthesia $\cdot$ Coronary artery bypass graft surgery $\bullet$ Cystatin C $\cdot$ Diabetes - Neutrophil gelatinase-associated lipocalin

\begin{abstract}
Background/Aims: Cardiac surgery and diabetes are major causes of acute kidney injury (AKI). We aimed to investigate the value of urinary neutrophil gelatinase-associated lipocalin (NGAL) and serum cystatin C, as early biomarkers for prediction of AKI in diabetic and nondiabetic adult patients undergoing cardiac surgery. Methods: 15 non-diabetic and 15 diabetic adult patients undergoing cardiac surgery were enrolled. Peri-operative clinical and laboratory variables were recorded. Urinary NGAL, serum cystatin C, serum creatinine (Cre) and blood urea nitrogen (BUN) were evaluated. Results: AKI was detected in 4 patients in non-diabetic group and 12 patients in diabetic group. Urinary NGAL levels of diabetic and non-diabetic patients and serum cystatin $C$ levels of diabetic patients exceed upper normal limits or cut off values much earlier than BUN and Cre. cystatin $C$ levels of non-diabetic patients remain unchanged. Cystatin C and NGAL levels of patients meeting AKI criteria and NGAL levels of patients not meeting AKI criteria exceeded upper normal limits or cut off values much earlier in than BUN and Cre. Conclusions: Measurement of cystatin C level in both diabetic and nondiabetic patients may reveal AKI earlier than NGAL and BUN. In diabetic patients, measurement of urinary NGAL and serum cystatin C levels may indicate AKI signs earlier than BUN and Cre.
\end{abstract}




\section{Kidney \\ Blood Pressure Research}

Kidney Blood Press Res 2015;40:141-152

\begin{tabular}{l|l}
\hline DOI: $10.1159 / 000368490$ & (C) 2015 S. Karger AG, Basel
\end{tabular}

Published online: March 22, 2015

www.karger.com/kbr

\section{Introduction}

Acute kidney injury (AKI) designates the condition previously called acute renal failure and represents a spectrum of renal diseases varying from minor elevations of serum creatinine (Cre) to anuric renal failure [1]. Cardiac surgery is one of the major causes of hospital-acquired AKI and the condition is known as cardiac surgery-associated AKI (CSAAKI) [2]. CSA-AKI is a probable serious complication associated with increased morbidity and mortality, prolonged intensive care unit stay, need for hemodialysis and great economic costs $[3,4]$. The incidence of CSA-AKI can approach to $50 \%$ [5] with a mortality rate of $1-5 \%$ [6]. Diabetes is a well-known independent risk factor for development of coronary artery disease and common in adult patients undergoing CABG surgery [7]. Diabetic patients were found to have significantly more diffused coronary artery stenosis and more end-organ dysfunction, including renal insufficiency.

Currently the early prediction of AKI by clinical and laboratory methods remains difficult. In clinical practice Cre level and urine output are the most frequently used indicators of renal dysfunction despite their limited sensitivity and specificity [8]. In diabetic patients undergoing coronary artery bypass graft (CABG) surgery due to the high risk of CSA-AKI, it is important to detect AKI as early as possible in order to implement potentially protective therapy. Several urinary proteins such as neutrophil gelatinase-associated lipocalin (NGAL), cystatin C, kidney injury molecule-1 (KIM-1) and interleukin-18 (IL-18) have been studied to assess their role as early biomarkers of AKI in patients undergoing cardiac surgery [9]. There is scarce information on the use of serum and urine urinary proteins as early predictive marker of postoperative AKI in adult diabetic patients undergoing CABG.

In this prospective controlled study we aimed to investigate the value of urinary NGAL and cystatin $\mathrm{C}$ as early biomarkers for prediction of AKI in diabetic and non-diabetic adult patients undergoing CABG surgery with normal preoperative renal function. Renal functions were assessed by BUN and Cre of which are routine clinical laboratory markers of kidney function, and by urinary NGAL and serum cystatin $\mathrm{C}$ of which are considered as subclinical and sensitive markers of glomerular and tubular damage.

\section{Material and Methods}

\section{Study design and patient population}

After university ethics committee approval, patients 50-85 years of age undergoing CABG surgery at Selcuk University Hospital were enrolled in this study. The patients were informed about the purpose of the study and written informed consent was obtained from each patient. Patients who do not have various factors that may affect renal functions such as pre-existing history of renal or hepatic failure, heart failure, acute or chronic pulmonary disease, pulmonary artery hypertension, previous cardiac surgery, malignancy, liver, thyroid, or infectious diseases; severe proteinuria ( $>3.5 \mathrm{~g} / \mathrm{d}$ ), inflammatory states; alterations in leukocyte count or formula; and treatment with steroids, history of potential nephrotoxic use during the preoperative days were considered eligible for the study. Consecutive diabetic and non-diabetic patients meeting the above criteria were enrolled in the study.

Data from patients requiring surgical revision for any reason, receiving mechanical ventilation for more than $12 \mathrm{~h}$ and patients with preoperative or postoperative inotropic support were excluded from the study. Data of patients who died during the first 48 hours were also excluded.

\section{Anesthetic Plan}

Oral $10 \mathrm{mg}$ of diazepam was administered to each patient for premedication on the previous night and one hour before anesthesia induction. Anesthesia induction was achieved with $0.3 \mathrm{mg} / \mathrm{kg}$ of etomidate, 0.5 $\mathrm{mg} / \mathrm{kg}$ of rocuronium, and $5 \mathrm{mcg} / \mathrm{kg}$ of fentanyl. Anesthesia was maintained with sevoflurane in a mixture of $50 \%$ oxygen and $50 \%$ air using a semi-closed circle system with a soda lime canister before cardiopulmonary bypass (CPB) and 1-2\% sevoflurane during CPB. Also for maintenance, $0.2 \mathrm{mg} / \mathrm{kg}$ of rocuronium and $5 \mathrm{mcg} /$ $\mathrm{kg}$ of fentanyl were added at the beginning of the surgery and before and after the CPB. 


\section{Kidney \\ Blood Pressure Research}

Kidney Blood Press Res 2015;40:141-152

\begin{tabular}{l|l}
\hline DOI: $10.1159 / 000368490$ & (C) 2015 S. Karger AG, Basel
\end{tabular}

Published online: March 22, 2015

www.karger.com/kbr

Heparin sulphate $(300 \mathrm{U} / \mathrm{kg}$ ) was given prior to cannulation. Activated clotting time (Hemochron 80, International Technidyne Corp., NJ, USA) was kept at $\geq 400 \mathrm{~s}$ during extracorporeal circulation. At the end of CPB circulating heparin was antagonized by protamine $(3 \mathrm{mg} / \mathrm{kg})$, and additional doses of protamine were given if needed.

DeBakey roller pump, membrane oxygenator non-pulsatile flow $\left(2.4 \mathrm{~m}^{2} / \mathrm{min}\right)$ and mild hypothermia $\left(28^{\circ} \mathrm{C}\right)$ were used for CPB. Priming fluid of the CPB pump consisted of balanced electrolyte solution and $1 \mathrm{~g} /$ $\mathrm{kg}$ of $20 \%$ Mannitol. Standard cold blood cardioplegia was used at a dose of $15 \mathrm{~mL} / \mathrm{kg}$. The hematocrit level in CPB was kept $\geq 30 \%$.

The $\mathrm{pH}$ of the patient was kept within normal range. In case of hyperglycemia insulin infusion therapy was started and blood glucose levels were kept below $200 \mathrm{mg} / \mathrm{dl}$. The insulin infusion rate was adjusted to maintain perioperative blood glucose levels between 150-200 mg/dL. At the end of surgery, patients were transported to the intensive care unit. The same anesthesia and surgical teams performed all operations.

\section{Data Collection}

As part of routine clinical practice, data were collected prospectively during the patient's admission on the following variables: age, sex, body mass index, urgency of operation, prior cardiac surgery, history of myocardial infarction, smoking, diabetes, hypercholesterolemia, hypertension, peripheral vascular disease, cerebrovascular disease, respiratory disease, and renal dysfunction. Pre-operative clinical and laboratory variables as well as the extent of coronary artery disease, and left ventricular ejection fraction, and intraoperative variables including the number and type of grafts, the use of CPB, CPB perfusion time and aortic cross clamping time, duration of operation and anesthesia, and data regarding hemodynamic parameters, urine output, data regarding furosemide treatment, blood and blood product requirements, and total amount of drainage were recorded. First blood samples (baseline, $\mathrm{t} 1$ ) for cystatin C, Cre and Blood Urea Nitrogen (BUN) were collected before anesthesia induction. First urine sample for NGAL was collected after placement of urinary catheter immediately after induction. Further blood and urine samples were collected at the end of the operation ( $\mathrm{t} 2)$, and at $12^{\text {th }}(\mathrm{t} 3), 24^{\text {th }}(\mathrm{t} 4)$, and $48^{\text {th }}(\mathrm{t} 5)$ hours after admission to the intensive care unit (ICU).

\section{Measurement of biomarkers}

Blood samples for cystatin $C$ were centrifuged and the serum aliquot for storage at $-80{ }^{\circ} \mathrm{C}$. Serum cystatin $\mathrm{C}$ levels were quantified by nephelometry according to the manufacturer's instructions, using a BN2 nephelometry (Siemens Healthcare Diagnostics, UK).

Urine samples were centrifuged and the supernatants stored in tubes at $-80{ }^{\circ} \mathrm{C}$. Urine levels of NGAL were assayed by a two-step sandwich assay microparticul chemiluminescence immunoassay method by using Architect I2000 SR analyzer (Abbott Diagnostics, IL, USA). High affinity antibodies were generated toward distinct epitopes on NGAL and assay standards were prepared using human recombinant NGAL. Urine NGAL concentrations were measured using the standardized manufacturer's protocol in the range of 0-1,000 ng/mL. Serial dilution was performed where measured values exceeded this range.

\section{Outcome measures}

Diagnoses of postoperative AKI were made in accordance with the International Kidney Disease: Improving Global Outcomes (KDIGO) definition of AKI [10]. AKI is defined as any of the following: Increase in Cre by $\geq 0.3 \mathrm{mg} / \mathrm{dL}$ within 48 hours; or increase in Cre to $\geq 1.5$ times baseline, which is known or presumed to have occurred within the prior 7 days or urine volume $<0.5 \mathrm{ml} / \mathrm{kg} / \mathrm{h}$ for 6 hours. Normal range of BUN, Cre, and cystatin $\mathrm{C}$ were accepted as 18-55 mg/dL, 0.7-1.2 mg/dL, 0.58-1.02 mg/L, respectively [11]. Cut-off level for urinary NGAL was accepted as $65 \mathrm{ng} / \mathrm{mL}$ [12].

\section{Statistical analysis}

All data were entered and processed by SPSS 16.0 (SPSS Inc., IL, USA) for Windows statistical package. All data were expressed as mean and standard deviation (mean \pm SD) or median (95\% confidence intervals) unless otherwise indicated. All categorical variables were tested by chi-square test. All normally distributed continued variables (tested by Kolmogorov-Smirnov test) were compared between diabetic and nondiabetic groups using student t-test. In parameters that are not normally distributed, Mann-Whitney U-test 


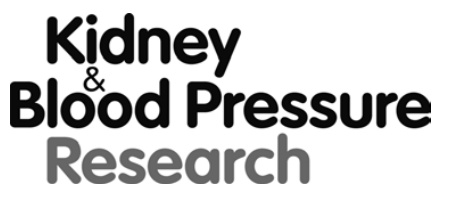

Kidney Blood Press Res 2015;40:141-152

DOI: $10.1159 / 000368490$

Published online: March 22, 2015

(C) 2015 S. Karger AG, Basel

www.karger.com/kbr

Arun/Celik/Oc/Unlu/Celik/Oc/Duman: Renal Effects of Coronary Artery Bypass Graft Surgery in Diabetic and Non-Diabetic Patients

\begin{tabular}{|c|c|c|c|}
\hline $\begin{array}{lr}\text { Table 1. Com- } \\
\text { parison of }\end{array}$ & & $\begin{array}{l}\text { Non-diabetic } \\
(\mathrm{n}=15)\end{array}$ & $\begin{array}{c}\text { Diabetic } \\
(\mathrm{n}=15)\end{array}$ \\
\hline non-diabetic & Gender $(\mathrm{F} / \mathrm{M})$ & $4 / 11$ & $4 / 11$ \\
\hline ups regar- & Age (Months) & $70,87 \pm 4,62$ & $72.87 \pm 6.06$ \\
\hline ng demogra- & Body weight $(\mathrm{kg})$ & $77,87 \pm 8,36$ & $80,27 \pm 9,68$ \\
\hline ic and ope- & Aortic cross clamping time (minute) & $39,13 \pm 8,46$ & $38,40 \pm 6,99$ \\
\hline tional data & Cardiopulmonary bypass time (minute) & $58,4 \pm 13,23$ & $56,8 \pm 13,90$ \\
\hline alues & Duration of surgery (minute) & $186,33 \pm 24,96$ & $201 \pm 34,70$ \\
\hline \multirow[t]{2}{*}{ ean $\pm S D$ ) } & Duration of anesthesia (minute) & $216,67 \pm 26,7$ & $234,67 \pm 33,13$ \\
\hline & $\mathrm{HbA}_{1 \mathrm{c}}$ & $4,96 \pm 0,2$ & $6,82 \pm 0,7$ \\
\hline
\end{tabular}

was used. One-way analysis of variance with repeated measures test was used to evaluate time dependent change, the effect of group, and group-time interaction in parameters. In case of significance post hoc Scheffe test was used to compare two time point measurements. A p-value less than 0.05 were considered significant.

Since the increase in Cre expected is about $30 \%$ to $50 \%$ according to the KDIGO definition of AKI and the standard deviation of Cre within groups is as low as 0.15 the sample size required to detect AKI is relatively low. In a design of two groups with sample sizes of 15 each (total sample of 30 subjects) the power of detecting a $30 \%$ difference in Cre is over $90 \%$ (less than $10 \%$ probability of beta error, accepting a false null hypothesis) with a significance of 0.05 ( $5 \%$ probability of alpha error, rejecting a true null hypothesis).

\section{Results}

A total of 57 patients were eligible for the study. Two non-diabetic and 4 diabetic patients required ventilator support more than $12 \mathrm{~h}, 8$ non-diabetic and 12 diabetic patients required inotropic support, and 1 non-diabetic patient died in the early postoperative period and were excluded from the study. After the exclusions, the study was completed with 15 diabetic and 15 non-diabetic patients. According to above criteria, AKI was detected in 4 patients in non-diabetic group and 12 patients in diabetic group.

Demographic and operational data are listed in table 1 . There were no differences among groups regarding age, weight, sex, duration of CPB, operation and anesthesia, and aortic cross-clamping times. HbA1c levels were higher in diabetic patients than non-diabetic patients $(\mathrm{p}<0.05)$. In diabetic group 9 patients were having oral anti-diabetic treatment while 6 patients' serum glucose level was regulated with oral regimens.

Perioperative data regarding urine output, total drainage volume, time to extubation, time to ICU discharge and Hemoglobin $(\mathrm{Hb})$ values are listed in table 2. Time to extubation and ICU discharge were longer and postoperative $24^{\text {th }}$ and $48^{\text {th }}$ hour hemoglobin levels were lower in the diabetic group $(\mathrm{p}<0.05)$. The sensitivity, specificity, positive predictive and negative predictive values regarding urinary NGAL and serum cystatin $\mathrm{C}$ are presented in table 3.

Compared to pre-induction level, serum BUN levels showed a significant increase in both groups at $1^{\text {st }}, 12^{\text {th }}, 24^{\text {th }}$ and $48^{\text {th }}$ hours $(\mathrm{p}<0.05)$. Only the mean BUN level of the diabetic group exceeded the normal laboratory upper limit of $55 \mathrm{mg} / \mathrm{dL}$ at the $48^{\text {th }}$ hour (figure 1a). Similarly compared to pre-induction level, serum mean Cre levels increased significantly in both groups with the diabetic group mean Cre values reaching the upper laboratory limit of $1.2 \mathrm{mg} / \mathrm{dL}$ at the $48^{\text {th }}$ hour (figure $\left.1 \mathrm{~d}\right)(\mathrm{p}<0.05)$. Compared to pre-induction level serum mean cystatin $\mathrm{C}$ levels of the diabetic group increased significantly exceeding upper limit of $1.02 \mathrm{mg} / \mathrm{L}$ at the $12^{\text {th }}$ hour $(\mathrm{p}<0.05)$. Changes in the serum cystatin $\mathrm{C}$ levels of the nondiabetic group were non-significant (figure 1c). Compared to pre-induction level, in both groups urinary mean NGAL levels increased significantly exceeding the cut-off value of 65 $\mathrm{ng} / \mathrm{mL}$ at the $12^{\text {th }}$ hour (figure $1 \mathrm{~b}$ ). 


\section{Kidney Blood Pressure Research}

\section{Kidney Blood Press Res 2015;40:141-152}

DOI: $10.1159 / 000368490$

Published online: March 22, 2015

(C) 2015 S. Karger AG, Basel

www.karger.com/kbr

Arun/Celik/Oc/Unlu/Celik/Oc/Duman: Renal Effects of Coronary Artery Bypass Graft Surgery in Diabetic and Non-Diabetic Patients

Table 2. Perioperative data of the patients

\begin{tabular}{|c|c|c|c|c|c|c|c|c|}
\hline & & $\begin{array}{c}\text { All } \\
\text { Patients } \\
(n=30)\end{array}$ & $\begin{array}{c}\mathrm{AKI}+ \\
(\mathrm{n}=16)\end{array}$ & $\begin{array}{c}\text { AKI - } \\
(n=14)\end{array}$ & $\begin{array}{c}\text { NDM AKI + } \\
(n=4)\end{array}$ & $\begin{array}{c}\text { NDM AKI - } \\
(n=11)\end{array}$ & $\begin{array}{c}\text { DM AKI + } \\
(n=12)\end{array}$ & $\begin{array}{c}\text { DM AKI - } \\
(n=3)\end{array}$ \\
\hline \multirow{4}{*}{$\begin{array}{l}\text { Urine } \\
\text { output } \\
\text { (ml) }\end{array}$} & $\begin{array}{l}\text { End of } \\
\text { operation }\end{array}$ & $1180 \pm 255$ & $1203 \pm 275$ & $1153 \pm 238$ & $1312 \pm 295$ & $1182 \pm 236$ & $1167 \pm 272$ & $1050 \pm 264$ \\
\hline & $\begin{array}{l}\text { Postoperative } \\
12^{\text {th }} \mathrm{h}\end{array}$ & $1685 \pm 332$ & $1675 \pm 308$ & $1696 \pm 368$ & $1562 \pm 473$ & $1709 \pm 397$ & $1712 \pm 250$ & $1650 \pm 300$ \\
\hline & $\begin{array}{l}\text { Postoperative } \\
24^{\text {th }} \mathrm{h}\end{array}$ & $1695 \pm 362$ & $1743 \pm 380$ & $1639 \pm 345$ & $1737 \pm 440$ & $1695 \pm 317$ & $1746 \pm 380$ & $1433 \pm 437$ \\
\hline & $\begin{array}{l}\text { Postoperative } \\
48^{\text {th }} \mathrm{h}\end{array}$ & $2988 \pm 774$ & $3159 \pm 793$ & $2793 \pm 730$ & $3125 \pm 781$ & $3023 \pm 648$ & $3171 \pm 832$ & $1950 \pm 100$ \\
\hline \multirow{3}{*}{$\begin{array}{l}\text { Diuretic } \\
\text { (mg) }\end{array}$} & $\begin{array}{l}\text { Postoperative } \\
12^{\text {th }} \mathrm{h}\end{array}$ & $31 \pm 19$ & $31 \pm 23$ & $30 \pm 15$ & $30 \pm 26$ & $29 \pm 16$ & $32 \pm 23$ & $33 \pm 12$ \\
\hline & $\begin{array}{l}\text { Postoperative } \\
24^{\text {th }} \mathrm{h}\end{array}$ & $39 \pm 22$ & $41 \pm 26$ & $36 \pm 16$ & $35 \pm 30$ & $36 \pm 17$ & $45 \pm 26$ & $33 \pm 12$ \\
\hline & $\begin{array}{l}\text { Postoperative } \\
48^{\text {th }} \mathrm{h}\end{array}$ & $47 \pm 20$ & $49 \pm 22$ & $41 \pm 17$ & $50 \pm 20$ & $44 \pm 18$ & $52 \pm 23$ & $33 \pm 12$ \\
\hline \multicolumn{2}{|c|}{ Total drainage } & $603 \pm 63$ & $617 \pm 59$ & $587 \pm 65$ & $612 \pm 66$ & $573 \pm 60$ & $619 \pm 59$ & $638 \pm 68$ \\
\hline \multicolumn{2}{|c|}{ Extubation time } & $500 \pm 48$ & $507 \pm 48$ & $493 \pm 48$ & $462 \pm 32$ & $479 \pm 42$ & $522 \pm 44$ & $547 \pm 22$ \\
\hline \multicolumn{2}{|c|}{ ICU discharge time } & $51 \pm 6.1$ & $53 \pm 6$ & $48 \pm 5.5$ & $47 \pm 3.5$ & $47 \pm 4.7$ & $54 \pm 5.5$ & $55 \pm 4.1$ \\
\hline \multirow{5}{*}{$\mathrm{Hb}(\mathrm{gr} / \mathrm{dL})$} & Preoperative & $13.3 \pm 1.3$ & $13.4 \pm 1.5$ & $13.2 \pm 1.2$ & $14.5 \pm 1.3$ & $13.2 \pm 1.3$ & $13 \pm 1.4$ & $13.1 \pm 0.4$ \\
\hline & $1^{\text {st }}$ hour & $10.3 \pm 0.9$ & $10.5 \pm 1$ & $10.1 \pm 0.9$ & $10.7 \pm 1.2$ & $10 \pm 1$ & $10.4 \pm 1$ & $10.4 \pm 0$ \\
\hline & $12^{\text {th }}$ hour & $10.7 \pm 0.8$ & $10.8 \pm 0.9$ & $10.6 \pm 0.6$ & $11 \pm 1.1$ & $10.7 \pm 0.7$ & $10.7 \pm 0.9$ & $10.6 \pm 0.4$ \\
\hline & $24^{\text {th }}$ hour & $11 \pm 0.7$ & $10.9 \pm 0.7$ & $11.2 \pm 0.7$ & $11.7 \pm 0.4$ & $11.5 \pm 0.6$ & $10.6 \pm 0.5$ & $10.3 \pm 0.4$ \\
\hline & $48^{\text {th }}$ hour & $11.3 \pm 0.5$ & $11.2 \pm 0.5$ & $11.4 \pm 0.6$ & $11.4 \pm 0.3$ & $11.6 \pm 0.4$ & $11.2 \pm 0.6$ & $10.6 \pm 0.2$ \\
\hline \multirow{3}{*}{ CABG } & 2 vessels & 10 & 6 & 4 & 1 & 3 & 5 & 1 \\
\hline & 3 vessels & 13 & 5 & 8 & 1 & 6 & 4 & 2 \\
\hline & 4 vessels & 7 & 5 & 2 & 2 & 2 & 3 & 0 \\
\hline \multirow{5}{*}{$\begin{array}{l}\text { Estimated } \\
\text { GFR } \\
(\mathrm{ml} / \mathrm{min})\end{array}$} & Preoperatative & $81.9 \pm 24.4$ & $91.3 \pm 27.2$ & $71.2 \pm 15.4$ & $104.3 \pm 27$ & $74.3 \pm 15.2$ & $86.9 \pm 27$ & $59.7 \pm 11.8$ \\
\hline & $1^{\text {st }}$ hour & $76.7 \pm 17.5$ & $75 \pm 17.7$ & $78.5 \pm 17.7$ & $75.1 \pm 19.6$ & $81.0 \pm 17.1$ & $75 \pm 18$ & $69.6 \pm 20.7$ \\
\hline & $12^{\text {th }}$ hour & $64.6 \pm 12.2$ & $63.2 \pm 12.6$ & $66.1 \pm 11.9$ & $59.7 \pm 15.8$ & $70 \pm 9.6$ & $64.3 \pm 11.9$ & $51.9 \pm 8.4$ \\
\hline & $24^{\text {th }}$ hour & $62.2 \pm 11.6$ & $61.1 \pm 12.6$ & $63.4 \pm 10.8$ & $61.4 \pm 13.9$ & $64.9 \pm 9.3$ & $61 \pm 12.8$ & $57.9 \pm 16.1$ \\
\hline & $48^{\text {th }}$ hour & $60.2 \pm 14.2$ & $53.8 \pm 10.4$ & $67.4 \pm 14.9$ & $58.4 \pm 12.4$ & $71.4 \pm 13.2$ & $52.3 \pm 9.2$ & $52.6 \pm 12.2$ \\
\hline
\end{tabular}

Notes: Values are mean \pm SD; Hb: Hemoglobin, ICU: Intensive Care Unit, CABG: Coronary artery by-pass graft; GFR: Glomerular filtration rate; AKI: Acute kidney injury; DM: Diabetic; Non-DM: Non-diabetic.

Compared to non-diabetic group, serum cystatin $\mathrm{C}$ levels were significantly higher in the diabetic group at $1^{\text {st }}, 12^{\text {th }}, 24^{\text {th }}$ and $48^{\text {th }}$ hours (figure $1 \mathrm{c}$ ). Similarly urine NGAL levels were also significantly higher in the diabetic group at $12^{\text {th }}$ and $24^{\text {th }}$ hours (figure $1 \mathrm{~b}$ ). When two groups were compared, BUN and Cre levels showed similar gradual increase with BUN exceeded and Cre reached the upper normal limits at $48^{\text {th }}$ hour, which was significantly higher in the diabetic group (figure $1 \mathrm{a}, \mathrm{d})(\mathrm{p}<0.05)$.

When the patients met the AKI criteria (AKI+) were compared to other patients (AKI-), BUN level at the $48^{\text {th }}$ hour was significantly higher in AKI+ patients $(p<0.05)$ but all BUN values in both groups were under upper limit (figure 2a). NGAL values at pre-induction and $48^{\text {th }}$ hour were significantly higher in AKI+ patients $(\mathrm{p}<0.05)$ and the $12^{\text {th }}$ and $24^{\text {th }}$ hour values in both AKI+ and AKI- patients, and $48^{\text {th }}$ hour value of AKI+ patients exceeded the cut-off value of NGAL (figure $2 \mathrm{~b}$ ). When two groups were compared; cystatin $\mathrm{C}$ levels of AKI+ patients were significantly higher at $1^{\text {st }}, 12^{\text {th }}, 24^{\text {th }}$ and $48^{\text {th }}$ hours and only the cystatin $\mathrm{C}$ values of $\mathrm{AKI}+$ patients at $12^{\text {th }}$ and $24^{\text {th }}$ hour exceeded the normal upper limit of cystatin $\mathrm{C}$ (figure 2c).

For Cystatin $\mathrm{C}$ and urinary NGAL, the area under the receiver operating characteristics (ROC) curves and $p$ values were presented at Table 4 . For cystatin $C$, there was statistically significance at the $1^{\text {st }}, 12^{\text {th }}, 24^{\text {th }}$ and $48^{\text {th }}$ hour and the area under the ROC curve was $0.737,0.768$, 0.786 and 0.719 , respectively. For urinary NGAL, there was not any statistically significance at any testing time. For Cystatin $C$ at the postoperative $1^{\text {st }}$ hour, a cut off value of $0.76 \mathrm{mg} / \mathrm{dL}$ 


\section{Kidney \\ Blood Pressure Research}

revealed a sensitivity of $75 \%$ and a specificity of $65 \%$. A cut off value of 0.98 $\mathrm{mg} / \mathrm{dL}$ at the postoperative $12^{\text {th }}$ hour had $75 \%$ sensitivity and $80 \%$ specificity. At the postoperative $24^{\text {th }}$ hour, a cut off value of 0.83 $\mathrm{mg} / \mathrm{dL}$ revealed 93\% sensitivity and $79 \%$ specificity while at the postoperative $48^{\text {th }}$ hour, a cut off value off $0.73 \mathrm{mg} / \mathrm{dL}$ gave $81 \%$ sensitivity and $72 \%$ specificity.

\section{Discussion}

Data from this study show that urinary NGAL levels of diabetic and non-diabetic

patients and serum cystatin C levels of diabetic patients undergoing CABG surgery exceed upper normal limits or cut off values much earlier than BUN and Cre that are the frequently used serum biomarkers of AKI. Serum cystatin C levels of non-diabetic patients remain unchanged. Serum cystatin C and urinary NGAL levels of patients meeting AKI criteria and urinary NGAL levels of patients not meeting AKI criteria exceeded upper normal limits or cut off values much earlier in than BUN and Cre.

Adult patients undergoing cardiac surgery are heterogeneous and may have limited renal function at baseline. Furthermore kidney function can be affected adversely from multiple factors such as changes in perfusion pressure, sympathetic tone, hematocrit level, and body temperature and due to hemolysis, transfusion of blood products, and inflammation during and after extracorporeal circulation period. Besides these operational factors diabetes may solely cause renal insufficiency after clinical insults. Our study was designed to control most of the factors mentioned above other than diabetes that can affect both tubular and glomerular kidney function and consequently total of 27 patients were excluded from the study. In this way we aimed to exclude other factors that can affect the performance of NGAL and cystatin C in order to focus on diabetic patients. Our data show that both groups were similar regarding perioperative bleeding, extracorporeal circulation parameters and cardiovascular stability.

Table 3. The sensitivity, specificity, positive predictive value and negative predictive

\begin{tabular}{|c|c|c|c|c|c|c|}
\hline & & & Sensitivity & Specificity & PPV & NPV \\
\hline \multirow{15}{*}{ CystatinC } & \multirow{5}{*}{ Non DM } & Preoperative & 0 & 1 & 0 & 0.73 \\
\hline & & $1^{\text {st }}$ Hour & 0 & 1 & 0 & 0.73 \\
\hline & & $12^{\text {th }}$ Hour & 0 & 1 & 0 & 0.73 \\
\hline & & $24^{\text {th }}$ Hour & 0 & 1 & 0 & 0.73 \\
\hline & & 48 th Hour & 0 & 1 & 0 & 0.73 \\
\hline & \multirow{5}{*}{ DM } & Preoperative & 0 & 1 & 0 & 0.2 \\
\hline & & $1^{\text {st }}$ Hour & 0 & 1 & 0 & 0.2 \\
\hline & & $12^{\text {th }}$ Hour & 0.5 & 0.33 & 0.75 & 0.14 \\
\hline & & $24^{\text {th }}$ Hour & 0.25 & 0.66 & 0.75 & 0.18 \\
\hline & & 48 $8^{\text {th }}$ Hour & 0.25 & 0.66 & 0.75 & 0.18 \\
\hline & \multirow{5}{*}{$\begin{array}{l}\text { DM+Non- } \\
\text { DM }\end{array}$} & Preoperative & 0 & 0 & 1 & 0.47 \\
\hline & & $1^{\text {st }}$ Hour & 0 & 0 & 1 & 0.47 \\
\hline & & $12^{\text {th }}$ Hour & 0.38 & 0.86 & 0.75 & 0.55 \\
\hline & & $24^{\text {th }}$ Hour & 0.19 & 0.92 & 0.75 & 0.5 \\
\hline & & 48 $8^{\text {th }}$ Hour & 0.19 & 0.92 & 0.75 & 0.5 \\
\hline \multirow{15}{*}{ NGAL } & \multirow{5}{*}{ Non DM } & Preoperative & 0 & 1 & 0 & 0.73 \\
\hline & & $1^{\text {st }}$ Hour & 0 & 1 & 0 & 0.73 \\
\hline & & $12^{\text {th }}$ Hour & 1 & 0.18 & 0.3 & 1 \\
\hline & & $24^{\text {th }}$ Hour & 0.75 & 0.27 & 0.27 & 0.75 \\
\hline & & 48 $8^{\text {th }}$ Hour & 0.25 & 0.63 & 0.2 & 0.7 \\
\hline & \multirow{5}{*}{ DM } & Preoperative & 0 & 1 & 0 & 0.2 \\
\hline & & $1^{\text {st }}$ Hour & 0.17 & 1 & 1 & 0.23 \\
\hline & & $12^{\text {th }}$ Hour & 0.91 & 0 & 0.78 & 0 \\
\hline & & $24^{\text {th }}$ Hour & 1 & 0 & 0.8 & 0 \\
\hline & & $4^{\text {th }}$ Hour & 0.75 & 0 & 0.75 & 0 \\
\hline & \multirow{5}{*}{$\begin{array}{l}\text { DM+Non- } \\
\text { DM }\end{array}$} & Preoperative & 0 & 1 & 0 & 0.47 \\
\hline & & $1^{\text {st }}$ Hour & 0.11 & 1 & 1 & 0.43 \\
\hline & & $12^{\text {th }}$ Hour & 0.94 & 0.14 & 0.56 & 0.67 \\
\hline & & $24^{\text {th }}$ Hour & 0.94 & 0.21 & 0.58 & 0.75 \\
\hline & & $48^{\text {th }}$ Hour & 0.63 & 0.54 & 0.63 & 0.54 \\
\hline
\end{tabular}

Notes: NGAL, neutrophil gelatinase-associated lipocalin; DM, Diabetes Mellitus; PPV, Positive predictive value; NPV, Negative predictive value. 


\section{Kidney Blood Pressure Research}

\section{Kidney Blood Press Res 2015;40:141-152}

DOI: 10.1159/000368490

Published online: March 22, 2015

(c) 2015 S. Karger AG, Basel

www.karger.com/kbr

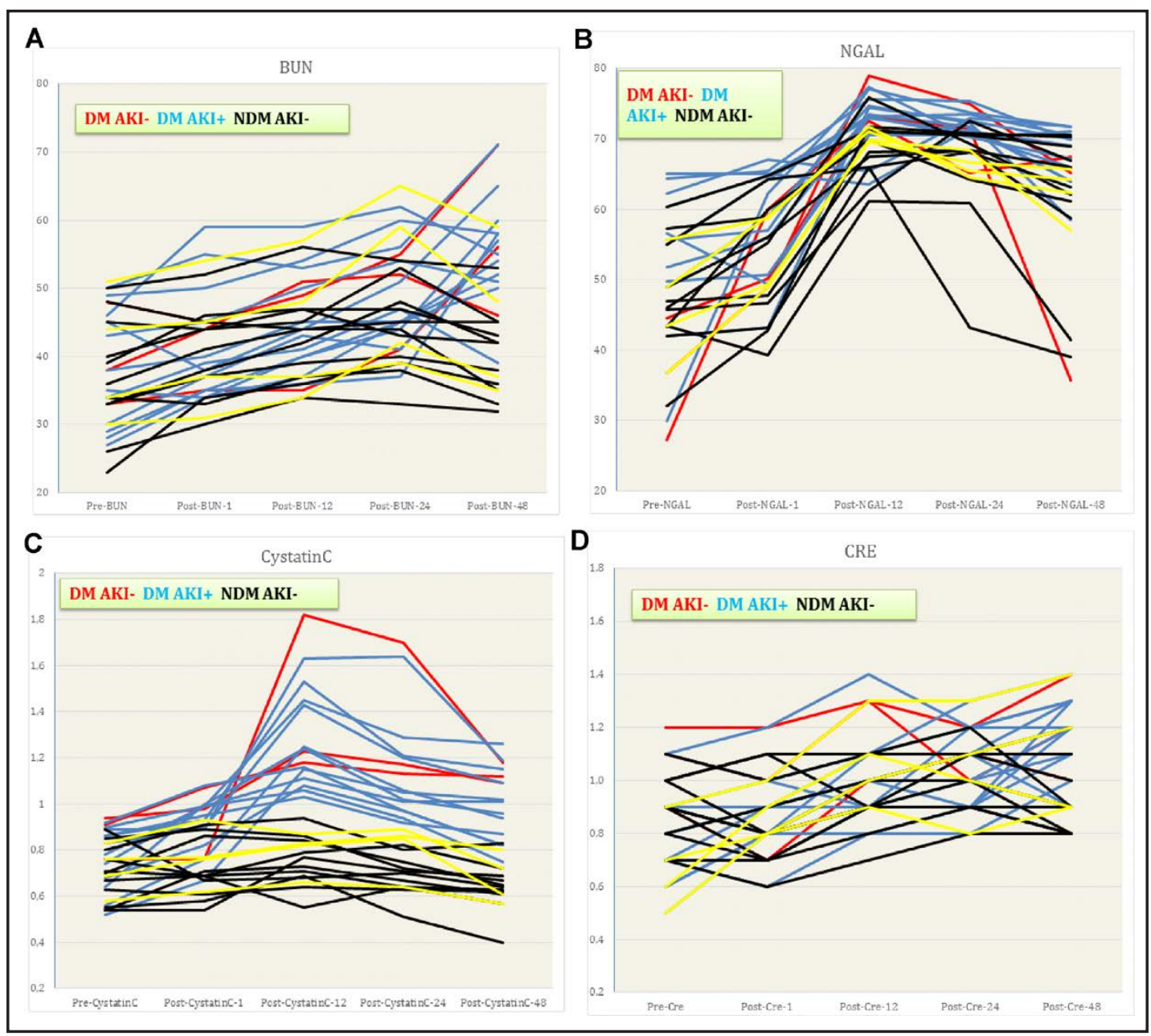

Fig. 1. Comparison of DM AKI- (Diabetic acute kidney injury -), DM AKI+ (Diabetic acute kidney injury +), NDM AKI- (Non-diabetic acute kidney injury -), NDM AKI+ (Non-diabetic acute kidney injury +) patients. BUN: serum blood urea nitrogen, Cre: serum creatinine, NGAL: Urinary neutrophil gelatinase-associated lipocalin, Cys: Serum cystatin C. Measurement times: $\mathrm{t} 1$; before anesthesia induction, $\mathrm{t} 2$; end of operation, $\mathrm{t} 3$; postoperative $12^{\text {th }}$ hour, t4; postoperative $24^{\text {th }}$ hour and postoperative $48^{\text {th }}$ hour. (A) Serum BUN levels (mg/ dL). (B) Urinary NGAL levels (ng/mL). (C) Serum Cystatin-C levels (mg/dL). (D) Serum Cre levels (mg/dL).

Despite advances in its management, AKI still adversely affects the outcome of CABG. Therefore, early detection of deterioration in kidney functions and to protect the kidney with an early and effective treatment is crucial. Although in routine clinical practice BUN and $\mathrm{Cr}$ continue to be the markers of renal function, levels of these markers can be affected by several extra-renal factors. Moreover, their elevation can be too late for early diagnosis of AKI and they do not provide any information about the nature or site of kidney injury. NGAL and cystatin C are well-known examples of promising sensitive markers of tubular and glomerular injury $[9,13]$.

NGAL is released early after tubular inflammation and ischemia as a renal stress biomarker and can be detected easily in the blood and urine due to small molecular size and resistance to biodegradation [14]. Recently, a large multicentre study assessed the early predictive value of NGAL in 1219 adults and found that NGAL concentrations peaked in urine or plasma within six hours after cardiac surgery [15]. In a smaller single-centre adult cardiac surgery 


\section{Kidney Blood Pressure Research}

Arun/Celik/Oc/Unlu/Celik/Oc/Duman: Renal Effects of Coronary Artery Bypass Graft Surgery in Diabetic and Non-Diabetic Patients

study, it was shown that NGAL levels in CSA-AKI patients rapidly rise and precede Cre by $>24$ hours [16]. Most recent meta-analysis has concluded that NGAL measured after cardiac surgery can predict the subsequent development of AKI in both adult and pediatric patients [17]. The predictive value of NGAL after cardiac surgery depends on definition of $\mathrm{AKI}$ and increase with progressive severity of AKI [18]. Haase-Fielitz at al. [17] systematically reviewed the utility of plasma and urine NGAL measurements for the prediction of AKI in humans and they pointed out some limitations, including lack of published studies that adhere to diagnostic study guidelines, heterogeneity in AKI definition, the lack of uniformly applicable cutoff values and variability in the performance of commercially available NGAL
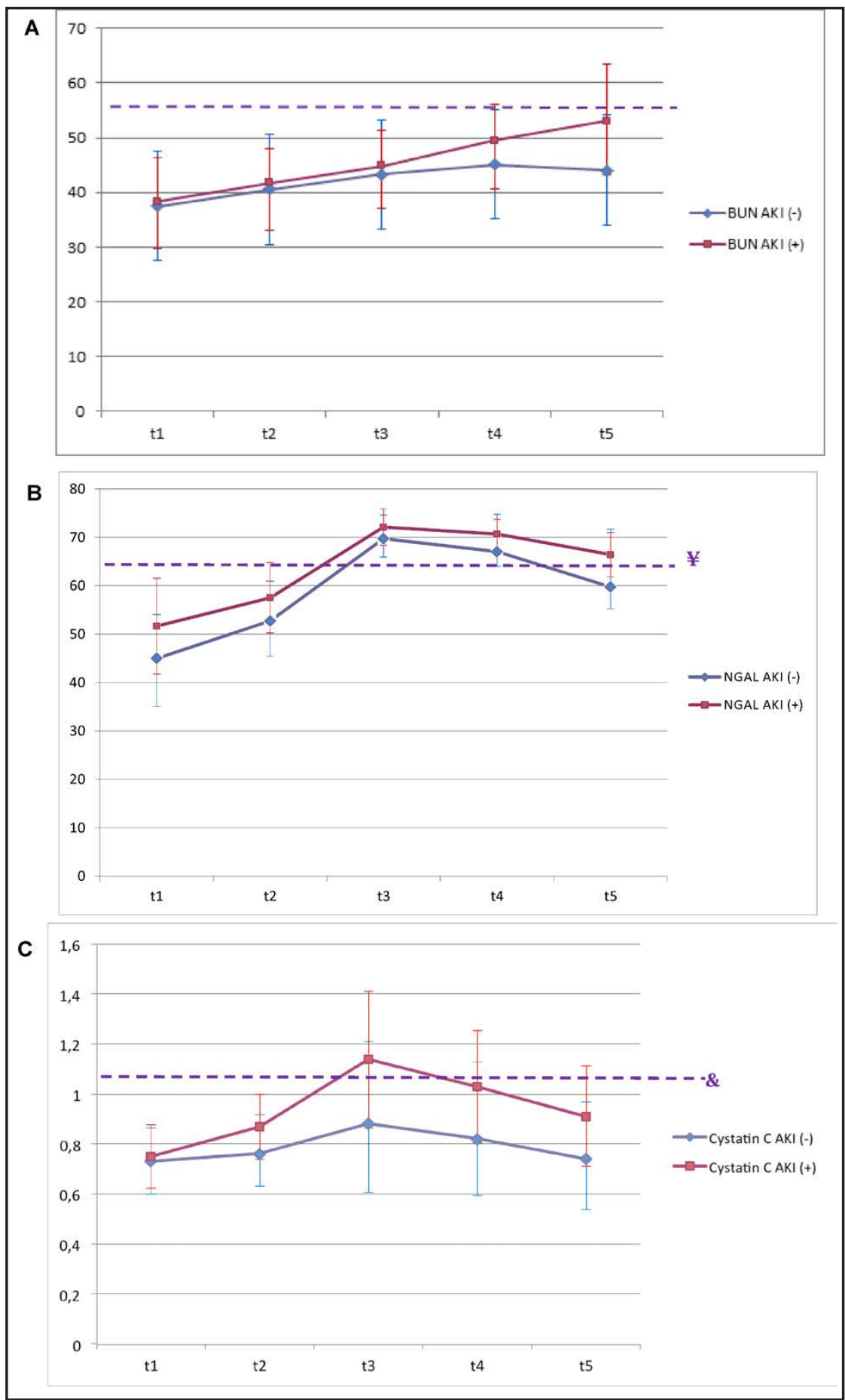

Fig. 2. Comparison $\mathrm{AKI}+$ and $\mathrm{AKI}-$ patients. $(\mathrm{AKI}+)$ : patients who meet, (AKI-): patients who do not meet acute kidney injury criteria. BUN: serum blood urea nitrogen, NGAL: urinary neutrophil gelatinase-associated lipocalin. Measurement times: $\mathrm{t} 1$; before anesthesia induction, $\mathrm{t} 2$; end of operation, $\mathrm{t} 3$; postoperative $12^{\text {th }}$ hour, $\mathrm{t} 4$; postoperative $24^{\text {th }}$ hour and postoperative $48^{\text {th }}$ hour. ${ }^{*} \mathrm{p}<0,05$ : between the groups. (A) Serum BUN levels (mg/dL). $\alpha$ : Dotted line depicting upper normal limit. (B) Urinary NGAL levels (ng/mL). $\alpha$ : Dotted line depicting upper normal limit. (C) Serum Cystatin C levels (mg/dL). \&: Dotted line depicting upper normal limit. 


\section{Kidney \\ Blood Pressure Research}

assays among studies. In the present study urinary NGAL showed a much earlier increase in both diabetic and non-diabetic patients but the increase in patients who met the AKI criteria was similar to BUN and Cre.

Cystatin C undergoes glomerular filtration instead of tubular filtration and it is not subject to any significant protein binding in contrast to creatinine. Cystatin C can indicate even small changes in the glomerular filtration rate so it is accepted as an attractive marker in the assessment of GFR [13]. Nevertheless the reliability of cystatin $\mathrm{C}$ as a predictor of renal function remains unclear. While some of the studies confirm the value of cystatin $C$ as a predictor of AKI in patients undergoing cardiac surgery $[13,19,20]$, some of them reported limited benefit $[21,22]$, and some of them found the sensitivity and specificity were lower for cystatin $C$ than for serum creatinine [23]. The reasons for the discrepancy are not clear but can attributable to the possible different perfusion techniques, the definition of AKI, cystatin $\mathrm{C}$ measurement times, and the population investigated. As an example, Spahillari et al. [23] found serum creatinine more sensitive and specific than cystatin $C$ but did not collect blood samples until $24 \mathrm{~h}$ after the operation in a large high-risk adult patient population undergoing urgent and complex procedures (e.g. triple valves, aortic surgery, redo's).

Liangos et al conducted a comparative analysis of 6 urinary biomarker candidates, KIM-1, NAG, NGAL, IL-18, cystatin C, and $\alpha-1$ microglobulin, for early detection of acute kidney injury following cardiopulmonary bypass [9]. In the analysis at the 2-hour post-CPB time point, urinary KIM-1 displayed the best diagnostic performance for detection of AKI, and was followed by IL-18 while urinary NGAL, cystatin C, $\alpha-1$ microglobulin, and NAG did not adequately make prediction. This is also consistent with our NGAL results. The timing of biomarker measurement after surgery is important. Recently Krawczeski et al. investigated four AKI biomarkers in a large group of children undergoing cardiac surgery [24]. Their results showed that urinary NGAL had excellent predictive value independent of the timing of its measurement and was the only biomarker with predictive value as early as 2 hours after surgery.

In the pathophysiology of diabetic nephropathy, tubular damage is also an important factor in addition to glomerular damage with the metabolic and hemodynamic injuring factors associated with sustained diabetic disease [25]. Particularly insulin-dependent diabetes is an independent risk factor for the development of acute renal failure in all types of cardiac surgery [26]. Insulin-dependent diabetes has a significant impact on in-hospital morbidity with regard to acute renal failure [27]. In our study all of the diabetic patients were to use oral diabetic medications instead of insulin therapy. 12 of the 15 diabetic and 4 of the 15 non-diabetic patients which were considered to have normal baseline preoperative renal function met the AKI criteria after CABG surgery. This high rate of renal deterioration after cardiac surgery in diabetic patients is consistent with an earlier report that accentuates the importance of early detection of AKI [28].

There is conflicting evidence regarding the prognostic value of NGAL and cystatin $\mathrm{C}$ in diabetic patients. Several tubular damage markers have been studied in this patient population. Nauta FL et al investigated the levels of kidney injury molecule (KIM)-1, N-acetyl$\beta$-D-glucosaminidase (NAG), NGAL, cystatin $\mathrm{C}$ and heart fatty acid binding protein (H-FABP)

Table 4. Area under the curve and p values of cystatin c and NGAL

\begin{tabular}{llcc}
\hline & & $\begin{array}{c}\text { Area Under } \\
\text { The Curve }\end{array}$ & $\begin{array}{c}\mathrm{p} \\
\text { value }\end{array}$ \\
\hline \multirow{3}{*}{ Cystatin C } & Preoperative & 0.547 & 0.662 \\
& ${\text { Postoperative } 1{ }^{\text {st }} \mathrm{h}}^{\text {Postoperative } 12^{\text {th }} \mathrm{h}}$ & 0.737 & 0.028 \\
& ${\text { Postoperative } 24^{\text {th }} \mathrm{h}}^{\text {NGAL }}$ & 0.768 & 0.013 \\
& Postoperative 48 & 0.786 & 0.008 \\
& Preoperative & 0.719 & 0.042 \\
\hline \multirow{3}{*}{ Postoperative $1{ }^{\text {st }} \mathrm{h}$} & 0.703 & 0.059 \\
& Postoperative $12^{\text {th }} \mathrm{h}$ & 0.683 & 0.088 \\
& Postoperative 24 & 0.663 & 0.129 \\
& Postoperative $48^{\text {th }} \mathrm{h}$ & 0.687 & 0.081 \\
\end{tabular}




\section{Kidney \\ Blood Pressure Research}

Kidney Blood Press Res 2015;40:141-152

\begin{tabular}{l|l}
\hline DOI: $10.1159 / 000368490$ & (C) 2015 S. Karger AG, Basel
\end{tabular}

Published online: March 22, 2015

www.karger.com/kbr

in a cross-sectional study and they concluded that only urinary H-FABP is associated with glomerular filtration rate (GFR) independently of albuminuria and, therefore, may be a promising urinary damage marker to assess diabetic kidney disease [29]. Nielsen et al. investigated the reliability of urinary excretion of various tubular markers; NGAL, H-FABP, KIM-1, and p-FGF23 in diabetic patients and they concluded that these markers did not provide additional prognostic information to that of known progression promoters [30]. Assal et al assessed serum cystatin C, urinary NAG and urinary NGAL in patients with type $2 \mathrm{DM}$ and their data indicated that urinary NAG is the most sensitive marker for early renal damage in diabetic patients, however, for damage progress, serum cystatin $C$ is the most sensitive and specific marker for follow-up and monitoring renal dysfunction [31]. In our study serum cystatin $C$ appeared as a sensitive and specific early marker for AKI.

For AKI biomarkers, new era has come and clinicians want to know which biomarker is the best for each situation and how to use for their patients. To our knowledge in the literature there is only one study that evaluates kidney injury comparing diabetic with non-diabetic patients undergoing cardiac surgery. In the mentioned study cystatin $\mathrm{C}$ was evaluated as a marker of mild renal insufficiency after CABG in diabetics and it was found that cystatin C and cystatin C-based estimation of GFR might be useful and more sensitive than Cre in detecting mild acute renal insufficiency [16]. Our results show that cystatin $C$ may be a candidate of good and early prediction of AKI in both diabetic and non-diabetic patients undergoing CABG surgery.

Although in this study we preferred to measure NGAL in urine, it can also be measured in blood. When urinary NGAL is assayed, normalized concentrations of excreted NGAL for urinary creatinine have been suggested to correct for differences in NGAL due to eliminate urine concentration as a factor [32]. In this study as a limitation, we did not measure urine creatinine and normalized ratio of urinary NGAL to urinary creatinine.

\section{Conclusion}

Measurement of serum cystatin C levels in patients undergoing CABG surgery in both diabetic and non-diabetic patients may point to the development of AKI much earlier than urinary NGAL and serum BUN. In diabetic patients, measurement of urinary NGAL and serum cystatin $C$ levels may indicate AKI signs much earlier than serum BUN and Cre. The use of serum cystatin $C$ values in early diagnosis of $A K I$ in patients undergoing CABG may be more effective than urinary NGAL, serum BUN and Cre. There is still need for further research with larger patient samples to assess true clinical value of these biomarkers in early diagnosis of AKI.

\section{Disclosure Statement}

The authors of this manuscript state that they do not have any conflict of interests and nothing to disclose.

\section{References}

1 American Society of Nephrology: American Society of Nephrology Renal Research Report. J Am Soc Nephrol 2005;16:1886-1903.

2 Garwood S: Cardiac surgery-associated acute renal injury: new paradigms and innovative therapies. J Cardiothorac Vasc Anesth 2010;6:990-1001. 


\section{Kidney \\ Blood Pressure Research}

Kidney Blood Press Res 2015;40:141-152

\begin{tabular}{l|l}
\hline DOI: $10.1159 / 000368490$ & (C) 2015 S. Karger AG, Basel
\end{tabular}

Published online: March 22, 2015

www.karger.com/kbr

3 Loef BG, Epema AH, Smilde TD, Henning RH, Ebels T, Navis G, Stegeman CA: Immediate postoperative renal function deterioration in cardiac surgical patients predicts in hospital mortality and long-term survival. J Am Soc Nephrol 2005;16:195-200.

4 Dasta JF, Kane-Gill SL, Durtschi AJ, Pathak DS, Kellum JA: Costs and outcomes of acute kidney injury (AKI) following cardiac surgery. Nephrol Dial Transplant 2008;23:1970-1974.

5 Haase M, Haase-Fielitz A, Bagshaw SM, Ronco C, Bellomo R: Cardiopulmonary bypass-asociated acute kidney injury: a pigment nephropathy? Contrib Nephrol 2007;156:340-353.

6 Thakar CV, Worley S, Arrigain S, Yared JP, Paganini EP: Influence of renal dysfunction on mortality after cardiac surgery: modifying effect of preoperative renal function. Kidney Int 2005;67:1112-1119.

7 Grover FL: A decade of change risk profiles and outcomes for isolated coronary artery bypass grafting procedures, 1990-1999. Ann Thorac Surg 2002;73:480-490.

8 Herget-Rosenthal S, Marggraf G, Hüsing J, Göring F, Pietruck F, Janssen O, Philipp T, Kribben A: Early detection of acute renal failure by serum cystatin C. Kidney Int 2004;66:1115-1122.

9 Liangos O, Tighiouart H, Perianayagam MC, Kolyada A, Han WK, Wald R, Bonventre JV, Jaber BL: Comparative analysis of urinary biomarkers for early detection of acute kidney injury following cardiopulmonary bypass. Biomarkers 2009;6:423-431.

10 KDIGO: Clinical Practice Guideline for Acute Kidney Injury. Kidney Int Suppl 2012;2:1-138.

11 Finney H, Newman DJ, Price CP: Adult reference ranges for serum cystatin C, creatinine and predicted creatinine clearance. Ann Clin Biochem 2000;1:49-59.

12 Mayo Clinic, Mayo Medical Laboratories, Biomarkers of Acute Renal Failure. http://www. mayomedicallaboratories.com/articles/hottopics/transcripts/2009/2009-8b-renal-failure/8b-18.html.

13 Dharnidharka VR, Kwon C, Stevens G: Serum cystatin C is superior to serum creatinine as a marker of kidney function: A meta-analysis. Am J Kidney Dis 2002;40:221-226.

14 Devarajan P: Emerging urinary biomarkers in the diagnosis of acute renal injury. Expert Opin Med Diagn 2008;2:387-398.

15 Parikh CR, Coca SG, Thiessen-Philbrook H, Shlipak MG, Koyner JL, Wang Z, Edelstein CL, Devarajan P, Patel UD, Zappitelli M, Krawczeski CD, Passik CS, Swaminathan M, Garg AX, TRIBE_AKI Consortium: Postoperative biomarkers predict acute kidney injury and poor outcomes after adult cardiac surgery. J Am Soc Nephrol 2011;22:1748-1757.

16 Schmidt-Ott KM, Mori K, Kalandadze A, Li JY, Paragas N, Nicholas T, Devarajan P, Barasch J: Neutrophil gelatinase-associated lipocalin-mediated iron traffic in kidney epithelia. Curr Opin Nephrol Hypertens 2006;15:442-449.

17 Haase-Fielitz A, Haase M, Devarajan P: Neutrophil gelatinase-associated lipocalin as a biomarker of acute kidney injury: a critical evaluation of current status. Ann Clin Biochem 2014;51:335-351.

18 Haase-Fielitz A, Bellomo R, Devarajan P, Bennett M, Story D, Matalanis G, Frei U, Dragun D, Haase M: The predictive performance of plasma neutrophil gelatinase-associated lipocalin (NGAL) increases with grade of acute kidney injury. Nephrol Dial Transplant 2009;24:3349-3354.

19 Abu-Omar Y, Mussa S, Naik MJ, MacCarthy N, Standing S, Taggart DP: Evaluation of Cystatin C as a marker of renal injury following on-pump and off-pump coronary surgery. Eur J Cardiothorac Surg 2005;27:893-898.

20 Momeni M, Baele P, Jacquet L, Mourad M, Waterloos H, Wallemacq P: Cystatin C in cardiac surgery. Acta Anaesthesiol Belg 2007;58:107-112.

21 Kiessling AH, Dietz J, Reyher C, Stock UA, Beiras-Fernandez A, Moritz A: Early postoperative serum cystatin C predicts severe acute kidney injury following cardiac surgery: a post-hoc analysis of a randomized controlled trial. J Cardiothorac Surg. 2014;9:10.

22 Koyner JL, Bennett MR, Worcester EM, Ma Q, Raman J, Jeevanandam V, Kasza KE, O’Connor MF, Konczal DJ, Trevino S, Devarajan P, Murray PT: Urinary cystatin C as an early biomarker of acute kidney injury following adult cardiothoracic surgery. Kidney Int 2008;74:1059-1069.

23 Spahillari A, Parikh CR, Sint K, Koyner JL, Patel UD, Edelstein CL, Passik CS, Thiessen-Philbrook H, Swaminathan M, Shlipak MG, TRIBE-AKI Consortium: Serum cystatin C- versus creatinine-based definitions of acute kidney injury following cardiac surgery: a prospective cohort study. Am J Kidney Dis 2012;60:922929. 


\section{Kidney \\ Blood Pressure Research}

\section{Kidney Blood Press Res 2015;40:141-152}

DOI: $10.1159 / 000368490$

Published online: March 22, 2015

C 2015 S. Karger AG, Basel

www.karger.com/kbr

Arun/Celik/Oc/Unlu/Celik/Oc/Duman: Renal Effects of Coronary Artery Bypass Graft Surgery in Diabetic and Non-Diabetic Patients

24 Krawczeski CD, Goldstein SL, Woo JG, Wang Y, Piyaphanee N, Ma Q, Bennett M, Devarajan P:

Temporal relationship and predictive value of urinary acute kidney injury biomarkers after pediatric cardiopulmonary bypass. J Am Coll Cardiol 2011;58:2301-2309.

25 Thomas MC, Burns WC, Cooper ME: Tubular changes in early diabetic nephropathy. Adv Chronic Kidney Dis 2005;12:177-186.

26 Luciani N, Nasso G, Gaudino M, Abbate A, Glieca F, Alessandrini F, Girola F, Santarelli F, Possati G: Coronary artery bypass grafting in type II diabetic patients: a comparison between insulin-dependent and noninsulin-dependent patients at short- and mid-term follow-up. Ann Thorac Surg 2003;76:1149-1154.

27 Kubal C, Srinivasan AK, Grayson AD, Fabri BM, Chalmers JA: Effect of risk-adjusted diabetes on mortality and morbidity after coronary artery bypass surgery. Ann Thorac Surg 2005;5:1570-1576.

28 Jarvela K, Maaranen P, Harmoinen A, Huhtala H, Sisto T: Cystatin C in diabetics as a marker of mild renal insufficiency after CABG. Ann Thorac Cardiovasc Surg 2011;3:277-282.

29 Nauta FL, Boertien WE, Bakker SJ, van Goor H, van Oeveren W, de Jong PE, Bilo H, Gansevoort RT: Glomerular and tubular damage markers are elevated in patients with diabetes. Diabetes Care 2011;4:975981.

30 Nielsen SE, Reinhard H, Zdunek D, Hess G, Gutiérrez OM, Wolf M, Parving HH, Jacobsen PK, Rossing P: Tubular markers are associated with decline in kidney function in proteinuric type 2 diabetic patients. Diabetes Res Clin Pract 2012;1:71-76.

31 Assal HS, Tawfeek S, Rasheed EA, El-Lebedy D, Thabet EH: Serum cystatin C and tubular urinary enzymes as biomarkers of renal dysfunction in type 2 diabetes mellitus. Clin Med Insights Endocrinol Diabetes 2013;6:7-13.

32 Tomonaga Y, Szucs T, Ambühl P, Nock S, Risch M, Risch L: Insights on urinary NGAL obtained in a primary care setting. Clin Chim Acta 2012;413:733-739. 